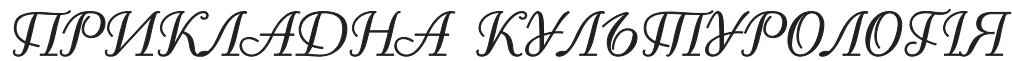

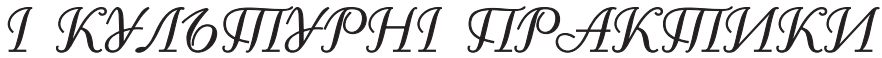

ORCID ID http://orcid.org/ 0000-0002-7855-966X

DOI: https://doi.org/10.37627/2311-9489-19-2021-1.144-154

\author{
THE PHENOMENON OF SONOR ENSEMBLE IN \\ THE CONTEXT OF THE CULTURAL PARADIGM SHIFT \\ AT THE TURN OF THE 21ST CENTURY
}

\author{
Samir Mirzayev \\ Ph.D. in History of Art, \\ Akdeniz University, \\ Antalya (Turkey) \\ rimasveozrim@gmail.com
}

\section{Самір Мірзоєв}

доктор філософії

3 мистецтвознавства,

Університет Акденіз,

м. Анталія (Турція)

rimasveozrim@gmail.com

\section{Самир Мирзоев}

доктор философии по искусствоведению, Университет Акдениз, г. Анталья (Турция) rimasveozrim@gmail.com
Abstract. Towards the end of the millennium, a once-vast empire had collapsed, causing a multitude of disruptions. This was an empire that had won World War II and become one of the world's superpowers for many decades; the empire that had created a completely new ideology and culture that had spread throughout many of its constituent nations as well as a number of neighboring countries. Music had been an important part of this culture. The demise of such a vast empire resulted, on one hand, in many of its component nations gaining liberty, but on the other, in various military, economic, and legal problems, among which should be mentioned a cultural and ideological vacuum. At the end of the last century, Azerbaijan, as well as other post-Soviet countries, was going through a period of crisis and culture shock, during which all governmental culture programs had been shut down. SoNoR, a contemporary music ensemble, appeared as an alternative to those programs during the darkest period of chaos. It was founded solely by a group of enthusiasts, and filled a cultural niche, becoming an image of contemporary music in the country for many years. SoNoR arranged concerts, festivals, workshops, and premieres both nationally and internationally. The band also established cultural exchanges with various countries. This article concerns the phenomenon of this group in the context of the turn of the century, as well as an attempt to analyze the main reasons for its ups and downs and eventual breakup.

Keywords: SoNoR ensemble, contemporary music, academic music, intercultural relationships, Azerbaijani music, alternative programs, concerts, festival, cultural dialogue.

Problem definition. The demise of the Soviet Empire at the end of the last century (millennium) caused all of the nations within the country, as well as neighboring states, to descend into economic, political, military, and cultural turmoil. It was a troublesome time for this vast territory, one which afterwards would be referred to as "the wild nineties". The newly-appeared post-Soviet countries were enveloped in mayhem. The juridical and ideological powerlessness of the states led to the depreciation of many values. One such value was culture: both in general, and in classi- 
cal music in particular. Almost all state music institutions were in turmoil; the ministries had no budgets; a massive brain drain was occurring; new currencies were rapidly devalued; higher education institutes and schools continued as though by rote. The majority of post-Soviet countries shared this fate to a greater or lesser extent. During the 1990s, Azerbaijan suffered greatly owing to the long-term military conflict that started between itself and its neighbor Armenia. The occupation of 20 percent of the territory, and the existence of around one million refugees from battle zones, aggravated the economic and political situation in the country. Under such conditions, having music concerts was out of the question, and in this country with a thousand-year music history, all cultural projects had been suspended. The funds to all subsidized government institutions were frozen. Concert parlors were empty, only occasionally opening their doors for sponsored events. During these dark times, however, a contemporary music ensemble called SoNoR appeared, unexpected by musicians and cultural officials alike, and started giving chamber concerts using their own resources. Young enthusiasts who were supported by their teachers and older friends in Baku founded the ensemble. From the mid-nineties, this musical group began to fill a huge niche in the cultural life of the capital city. They started working purely on sheer enthusiasm, but by the end of the century, the ensemble had managed to participate in international festivals representing their country. The initial trio turned into a quintet, then a septet, and by the beginning of the Millennium, the ensemble consisted of fifteen members, all of whom gave a triumphant performance at one of the most famous festivals in Europe. The ensemble performed both on TV and radio, and the phenomenon was reported by foreign and local newspapers alike, as well as science magazines. Their event posters sported logos of big international sponsoring organizations. State cultural organizations themselves even began to cooperate with the ensemble, despite their rivalry. The ensemble soon turned into the Initiative Center, which arranged festivals in Azerbaijan and became a private cultural organization, causing rivalry with state-financed organizations. SoNoR managed to organize that which older ministries with state budgets and personnel failed to. At the pinnacle of their career, the Initiative Center of Contemporary Music had connections with many famous musicians of Europe and Asia; they collaborated with various conductors and composers from more than a dozen countries, music was specifically written for them. It established cultural dialogues that translated into creative projects. During the mid-2000s, however, certain problems appeared in the Center's work. Public organizations regained some strength and started taking control over the musical domain. Government funds were allocated to support art of another, older type. Its allies were few, and its problems multiplied. Ten years after its foundation, the ensemble had to step down. SoNoR became a thing of the past.

The research problem: to identify the events preceding and associated with the peak and breakup of the ensemble, analyzing objective and subjective reasons for the appearance and decline of this phenomenon in the context of the time and post-Soviet space. Identifying the reasons can help to confirm or deflate possibilities of repetition of such phenomenon in similar cultural spheres.

Relevance. There is a growing number of young bands that are looking to make their own way in the modern world of music and performance. Classic lineups such as the string or wind quintet are too reminiscent of the academic sphere. The modern music world is more focused on multi-timbral groups. When creating such groups, musicians face various major challenges. This research is focused upon attempting to explain these challenges, as exemplified by the SoNoR ensemble.

Latest research. It should be noted that the ensemble had a very modern musical formation: not just chamber, wind, etc., but a multi-timbral one, with a representative of each mobile instrument (vocals, winds, strings, drums, piano). In fact, it was a team that was able to fulfill various musical projects. Musical literature (Pereverzeva, 2019) mentions similar ideas by the famous American composer Philip Glass at the end of the twentieth century. Just like Glass, SoNoR, from beginning to end, had a repertoire policy that was aimed at adjusting the musical lineup to the composer's work - and vice versa, adjustment of the composer to the existing ensemble, with each member being a potential soloist. The well-known Moscow musicologist Rauf Farhadov also speaks about phenomena that are similar in style and spirit, explaining N. Kholopova's concept of our current "Time of Individual Projects" (azlogos.ru, 2020), wherein each Artist has the right to change their style "as per each project". Only a flexible and multi-timbral mobile structure like SoNoR 
can adapt to each such artist's work, as each piece may be in a completely different style. The increased role of chamber and instrumental ensembles in contemporary composition is not an occurrence happening only in America and Europe. Such trends in research can be found in Russia (Makushkin, 2010) as well as in the post-Soviet space; for example, in Belarus (Orlova, 2008) and Azerbaijan (Dadashzade, 2002). The author focuses his research in this article on the history of a specific multi-timbral group.

The purpose of the article. To discover the concert chronology of the time and the entire chain of cultural events, to study the phenomenon of SoNoR ensemble and to assess its contribution to a new music history of post-Soviet Azerbaijan and the multicultural relationships that were established between many countries. The sequence of events will also help to identify periods of group's development and will pave the way for future research. It is also necessary to analyze and comprehend the role of temporal and cultural paradigms of that time which defined periods of the ensemble's ascent and extinction.

The Initiative Center of Contemporary Music (Ensemble) SoNoR that was founded in Baku exactly a quarter of a century ago was and remains the most inexplicable and unexpected phenomenon in the history of modern academic music in post-Soviet Azerbaijan. It was not a governmental or commercial organization, but this group of musicians managed to have existed for about 10 years (1995-2005), to perform with huge success in many countries and to promote an absolutely non-commercial type of music - the academic avant-garde. Over the years the group had actually represented Azerbaijan in the world of avantgarde music abroad and promoted the new world music throughout the country. SoNoR had organized festivals, concerts, workshops, theater performances and premieres of musical works in Baku practically out of sheer enthusiasm. And this all happened in the circumstances when many official musical organizations and institutions with considerable budgets and armies of employees not only existed in the country, but often actually created obstacles for the ensemble.

It was in summer of 1995 when four friends, four young musicians decided to form a contemporary music group. They were: a postgraduate student of Baku Academy of Music (BAM), a pianist Samir Mirzoev, a military orchestra clarinetist Nizami Zeynalov, a guitarist of the local rock group Rovshan Mamedov and a postgraduate student of BAM, a composer Elmir Mirzoev. The first composition the musicians had ever performed was Elmir Mirzoev's trio called "Symbolic Triangular Silence" (Mirzoev, 1995) which was composed specifically for friends' instruments: bass clarinet, guitar and grand piano. The members of the band had been meticulously learning this music piece for three weeks and performed it at the composer's examination at BAM. The piece symbolized three angles three friends - that formed together a single irrational dimension and by means of their unique instruments (keys, wind, and strings) served "the Great Silence" the Music.

First public concerts of SoNoR ensemble (the name consisted of the first letters of lead musicians' names - Samir, Nizami and Rovshan — played upon and turned into a musical term) took place in 1996 under the auspices of Yeni Musiqi - the Society for Contemporary Music. The first two projects ("Them and Us", "New Music of Russia") were two-day mini festivals that enabled various musicians to show their skills, whereas the third project ("The music concert of the Swiss composers") had brought another promising talent to the ensemble. It was a soprano named Farida Mamedova who had become a permanent lead singer of the group. Thus, the main lineup had formed; it was a quintet with the artistic director occasionally playing drums. In March 1997 the quintet SoNoR participat$e d$ in the one-off Plenum of the Composers Union of Azerbaijan that settled for this as a compromise, "ideological confrontation" notwithstanding. SoNoR (soprano, clarinet, guitar, drums and grand piano) was the highlight of the concert and caused a lot of controversy with its repertoire.

In 1997 SoNoR with the same instrumental formation started a collaboration with the cast of YUĞ theatre under tenure of the famous director Vagif Ibrahimoglu. This creative collaboration was quite fruitful and resulted in several modern productions, the most famous of which was a play called Lost time (Itmiş saat) that was basically a performance wherein the costumed musicians were the characters on stage along with the actors. Music to all of the productions was suggested and performed by the ensemble throughout the whole act. The strivings in this genre stopped in 1998 with the last collaborative stage performance called "Prelude to the return" ("Qayıdışa prelüd") that commemorated 80th birthday of Kara Karaev (featuring Galatea fashion house). By that time, the ensemble had 
been operating as Initiative Centre of Contemporary Music (ICCM).

1998 was the year when the ensemble entered an international stage. SoNoR together with Bakustic Jazz trio represented Azerbaijan at the International Art Festival "GIFT" which was held in Georgia and gathered dozens of bands from all over the world, from the USA to Cambodia. Brilliant performance at the international scene celebrated a successful completion of the ensemble's First Period - the formative period (1995-1998).

The Second Period (1999-2003) was a period of prosperity and genuine international recognition of the group. Over these years SoNoR had performed abroad more often than back at home and given concerts in countries like Belgium, Germany, Georgia, Holland, Estonia, Russia, the Czech Republic, Ukraine, Moldova, Uzbekistan and Mongolia. The ensemble formation grew and more first-class musicians joined the group, including a violinist Soltan Mamedova, cello players Eldar Iskenderov and Rasi Abdullaev, a pianist Yuri Sayutkin, a flutist Olga Bagirova, drummers Boris Pashkn and Firuz Mamedov and some others. The conductors from Austria (Roland Freisitzer, Peter Keuschnig), Ukraine (Volodymyr Runchak), Germany (Bernhard Wulff), Turkey (Elshad Bagirov) and Iran (Masoud Kazemzade) were invited to direct the expanded lineup. The ensemble performed in countries like Germany, Ukraine and Georgia many times.

This period started with a howling success in the capital of the Czech Republic in November 1999 at the New Music Marathon festival. Only composers who had won the preliminary competition were invited to give original concerts at this forum of contemporary academic music. The ensemble's artistic director Elmir Mirzoev won the competition and gained the right to give the original concert in Prague alongside the composers from Germany, the United Kingdom, Russia, the Czech Republic and Lithuania; several invited musicians participated in the project. The ensemble flawlessly performed its composer's pieces under the baton of Roland Freisitzer. The underground hall of Divadlo Archa theatre was filled with roars of applause and shuddered under the stamping feet of the excited audience. After the success at the New Music Marathon festival, R. Freisitzer had been collaborating with SoNoR for many years.

The beginning of the Millennium was a fruitful time for the ensemble: in 2000 the group participated in several massive international projects. By that time, they had had the manager, Afet Mamedova, who played a huge part in further work of the ensemble as she had an apparent organizational talent, connections in the business world and an academic musicologist background which made her an irreplaceable asset.

That year started with the contemporary music festival ILKHOM XX that took place in Tashkent and gathered interesting bands from all over the world. Such an unusual for the Central Asia forum was curated by the famous composer Dmitri YanovYanovsky. SoNoR attracted a lot of attention (with its repertoire first and foremost) from both colleagues and the audience despite the poor state of their instruments and made several useful contacts which was a common thing for events like this.

The ensemble toured the post-Soviet countries in September 2000; they gave double concerts in Baku (in the Church of the Saviour), in Moscow (in the Russian Composers Union hall), in Kishinev (in the hall of the National Arts Museum of Moldova) and a concert in the Conservatory of Tallinn and the University of Tartu (Estonia). This time another Austrian conductor worked with the ensemble alongside R. Freisitzer maestro Peter Keuschnig. For each conductor separate programs were planned; the implementation of this project required a coordination of actions of different organizations representing these countries as well as the international sponsoring institutions. Completely new compositions were written by foreign authors specifically for this project with the ensemble's instrumental lineup in mind.

In October, almost right after the tour was finished, the SoNoR Initiative Center was to organize an even larger event: the European Composers Informal Meeting (ECIM) in Azerbaijan, where the premiere performance of their works was planned to happen. Composers from more than ten countries came to Baku with their pieces specially written for the ensemble which had to work extremely hard: two concerts included performance of 11 world premieres in addition to other compositions. The ensemble had started receiving all of those music pieces even before the Eastern European tour happened; some of them the band tried to read while doing their existing program. Not all of the presented works were distinguished but there were also ones that had remained in the SoNoR repertoire for many years. Thus, one of the ensemble's hits called "Love: formal aspects" 
written by the Swedish composer Fredrik Österlink (Österlink, 2000) was performed back then and made an unforgettable impression on the public with its undisguised eroticism.

November of the year 2000 was also a very fruitful time. The International Festival "November Music" was interesting because the participants performed not in one city, but travelled to three countries of Western Europe (Germany, Holland, Belgium). SoNoR performed in three cities: Essen,'sHertogenbosch and Ghent, offering the audience their favorite compositions from the ECIM project such as: "Visions and Echo" by E. Mirzoev (Mirzoev, 2000), "Music for my daughter" by R. Freisitzer (Freisitzer, 2000) and "CRWTH" by François Sarhan (Sarhan, 2000) as well as "Cantabile... Dialoque im Raum" which was specifically written for the ensemble by their compatriot Ali Alizadeh (Alizadeh, 2000) and performed for the first time at the Festival.

The ensemble kept the same pace of work through the next year. In April 2001, SoNoR took part in two Ukrainian festivals at once: the famous "Two Days \& Two Nights of New Music" and the Festival of Improvised Music in Odessa. The first festival is known for its non-stop mode when various bands and soloists perform their programs regardless of the time of day. This unique format of the forum especially appealed to contemporary artists as it provided more communication and more creative contacts. It was there where our musicians established valuable contacts for future projects as, for example, a happy accident of meeting the Ukrainian conductor and composer Volodymyr Runchak - a talented and charming man who would have been associated with Azerbaijani contemporary music in general and with the ensemble in particular for many years to come, even after the breakup of the group. The second Odessa festival with its ethnic-improvisational subtext was, in a sense, the first step to future SoNoR projects that involved folk groups and ethnic music. It was by that time that the Azerbaijani folk instrument tar had been used for the first time in the ensemble and Gyulaga Zeynalov, a virtuoso tar player, had become a part of SoNoR for many projects.

After the ensemble had participated in the next project ("New Music from the Last Century" Festival) of the Yeni Musiqi Society in June, they began preparations for one of their most stellar performances: participation in the famous International Festival "Young
Euro Classic" in Berlin (Germany). To perform at that prestigious forum, the ensemble expanded the lineup to the biggest number of musicians they had ever had before -15 . Several composers were writing new pieces for the ensemble including the work of Aliya Mammadova "Səslərin səyahəti" ("The Journey of Sounds") for the mixed formation that featured the tar (Mammadova, 2001). The famous English composer James Clarke who was a representative of the New Complexity movement came to Baku to rehearse his composition called "Concetto spaziale" that had been specifically written for SoNoR for five performers (Clarke, 2001) and followed the ensemble to Berlin. The festival organizers commissioned a new work for Faradzh (Faraj) Karaev that had been written in the "free serialism" technique and would be presented for the first time in Berlin by SoNoR. That piece was called "Cancion de cuna" (Karaev, 2001) and written based on poems by F. Garcia Lorca and would create a sensation at the Festival.

SoNoR went to Berlin with a varied program: it was notable for not only vocals and accompanying people, but also for representation of acoustic, ethnic and electric instruments. Ukrainian conductor Volodymyr Runchak, whom the band had met only a few months before in Odessa, directed the performance. He had managed to win over the team over a short period of time and to present a complex work of maestro Karaev Jr. at a high level.

It was a perfect performance; the audience applauded vigorously and would not let the ensemble leave the Konzerthaus stage. It was subsequently referred to as one of the most successful performances of that Festival and was reported by such influential German newspapers as Die Welt (Klänge aus dem musikalischen Chemiebuch, 2001), Berliner Morgenpost (Von Mattias, 2001) and Berliner Zeitung (Von Peter, 2001). The title of the article in Berliner Morgenpost (August 13, 2001) spoke of the undeniable success: "The ensemble SoNoR from Azerbaijan outshone the Resonanz Ensemble" (Von Mattias, 2001). The lead SoNoR musicians: the pianist S. Mirzoev, the soprano F. Mamedova and the clarinetist N. Zeynalov were invited to a live broadcast of Berlin Radio the next day. There was no doubt that it was a triumph of the Initiative Center of Contemporary Music "SoNoR". On their way back to Baku, the ensemble gave two more concerts in Dresden. The band's close relationship with Germany continued over the next year and 
in February 2002 the Initiative Center together with the German embassy in Baku organized the Days of German and Azerbaijani Music called "SoNoR çarpaz yollarla" ("SoNoR Crossing Ways"). It was the project that involved concerts with premieres conducted by Elmir Mirzoev and Bernhard Wulff, workshops and other events.

In return, maestro B. Wulff invited SoNoR to participate in his exotic Festival in Mongolia. The project was called "Roaring hooves" and took place in the Gobi Desert (!) and was the farthest geographic point on the map of SoNoR performances. Due to technical difficulties and peculiarities of the location the ensemble was there in small numbers. At the end of the year the ensemble also played at the Faradzh Karaev event in Baku. The concert was organized under the auspices of Yeni Musiqi Society and was conducted by Elshad Bagirov.

The years spent on tours, established contacts and gained experience finally led to the natural outcome that was highly anticipated by the foreign colleagues: SoNoR decided to hold its own fullfledged international Festival in Baku. Thus, 2003 was decided to be the year of the SoNoR Initiative Center of Contemporary Music, which was supposed to appear before foreign friends as the organizer of festivals.

So, in February 2003 the International Festival of Traditional and Contemporary Music SoNoR Links: Dialogue of Cultures was held in Baku with the assistance of the Ministry of Culture of Azerbaijan, the German and Chinese Embassies, the British Council and Open Institute Foundation organizations and with the support of British Airways and others. The Festival was attended by representatives from 14 countries (England, Germany, Italy, Lithuania, Macedonia, Ukraine, Russia, Turkey, Iran, Kyrgyzstan, Uzbekistan, India, China and Japan): various ensembles and solo performers as well as musicologists and journalists. It was SoNoR's second triumph since after Berlin. It should be noted that the organizational talents of the artistic director E. Mirzoev and the manager A. Mamedova played a huge part in the success of the festival. Over a week three concerts a day were held in Baku - solo and collective performances of European and Asian musicians of completely different styles (avant-garde, jazz and ethnic music). The concerts took place at such stages as the Kapellhaus, The Rashid Behbudov State Song Theatre, Museum of Arts named after R. Mustafaev and the "10.33" club, but the main arena of the Festival was the Church of the Saviour, Baku. It was there where the ensemble gave its concert that consisted of old hits and was directed by the Berlin triumphant V. Runchak. The program also included the rarely performed "Sonata for Two Performers" (Karaev, 1976) by F. Karaev (duet of pianists S. Mirzoev, Yu. Sayutkin). The festival and its final concert in the infamous "10.33" club were widely covered in the mass media and had been remembered by the participants for a long time. This festival was marked as the end of the Second Period and the beginning of the Third Period of the well-known Initiative Center. The last stage in the development of SoNoR ensemble had begun.

The third, and final, Period in the history of the music group covered the period from the second half of 2003 to 2005 when SoNoR appeared to be more of an art projects organizer rather than an ensemble. In August 2003 another International Festival, "Asian Holidays", was held. But this project was dedicated exclusively to ethnic music performers, and had nothing to do with the contemporary music. The guests of "Asian Holidays" festival were long-time friends musicians from Azerbaijan, Iran, India and Kyrgyzstan.

As is well known, there is the other side of the coin when it comes to success. The organizational, financial, interpersonal and ideological problems accumulated over the years of the ICCM's existence had greatly shaken the initial friendly atmosphere of the team. Misunderstandings between the SoNoR members had become more common. At the same time the Yeni Musiqi Society, a long-time business partner as well as an ideological ally, also ceased to exist. The influence of musical government institutions that treated everything new fervently increased. The "wild nineties" in the context of the musical revolutionary romanticism became a thing of the past. It was extremely difficult to continue concert activity under these circumstances.

Out of the last five ICCM projects organized over 2003-2005, the ensemble, as a musical group, participated only in two. After the "SoNoR. Asian Holidays" festival (10-12.09.2003) there was the International Mini-Festival of Contemporary Art "Before the Symbol" ("Rəmzdən öncə") held in Capellhaus in June 2004 where the German "Ensemble reflexion $\mathrm{K}$ " performed and the artist Ali Herisci (Turkey) was exhibited. In October of the same year, the project "Fayyum Portraits - Living eternity" ("Fəyyum 
portretleri — Yaşadığımız əbədiyyət") was organized with the participation of SoNoR ensemble, the Iranian ethnic music band Mehr and the Shahin Novrasli jazz band. The concert took place at the Jazz Center in Baku.

The fourth (international) project out of the last five projects reminded of the former SoNoR most of all, when in October 2004 the friends in a small group (as sponsorship allowed) went to Georgia, to the "SaqARTvelo" Art Festival. The last performance of the ensemble as a musical group was at the amazing stage of the Tbilisi Theater of the Royal Quarter. It was a parity concert and Georgian musicians also participated in it. The atmosphere of the show was beautiful with the lights turned down as it was played by candlelight; the stunning visual effects could symbolically mean only one thing: "The ball is over, the candles are out..." Paraphrasing the poet, we can assume that it was a sign of a fading stage career. Indeed, time has shown that this concert was the last stage performance of the ensemble. Ironically, SoNoR's international performances began and ended in the same city.

As the passionate power of the ICCM decreased and the resistance of external factors increased, it became clear that the demise of the group was not far off. In April 2005, through the efforts of the SoNoR artistic director, the last project of the Center "Fəyyum portretlori II" with the participation of Swiss musicians was carried out in the Jazz Center of Baku. The festival was called after Elmir Mirzoev's composition of the same name that was performed among other opuses (Mirzoev, 2005). In 2005, the Initiative Center of Contemporary Music "SoNoR" seized to exist.

Former friends went each their own way; some had their personal projects, some went abroad, some dedicated their time to career. On rare occasions of friendly meetings, they gladly recalled their vibrant past. Only eight years later having accidentally heard an audio recording of the pianist S. Mirzoev from that very first international performance in Tbilisi, the Concert Department of the Izmir City Hall (Turkey) asked to arrange one last nostalgic "SoNoR" concert. The entire ensemble responded positively to the unexpected proposal, and the date of the concert was set for October 2013. But the unexpected and absurd death of clarinetist Nizami Zeynalov thwarted all plans. The concert never happened.

If you look at this whole story through the prism of the past quarter of a century, you can safely state that SoNoR left a bright mark in the history of contem- porary music development in post-Soviet Azerbaijan: about 40 concerts with various lineups (solo, duets, small and large lineups, mixed (with ethnic instruments) and parity with foreign musicians, costumed performances); organization of various Art Festivals (both contemporary and ethnic); performances in more than ten European and Asian countries; organization of concerts for many foreign famous musicians and ensembles in Baku (such as "TaG ensemble", "Ensemble reflexion K", "Sharunas Nakas ensemble", "Freiburg Percussion quartet", "Icarus", "Mehr", Christofer Jaqqin, Jaqueline Ott, etc.); involvement of foreign composers and conductors in Baku (such as Krzysztof Meyer, James Clark); organization of world premieres of music pieces for composers of Azerbaijan and other countries at various concert venues around the world.

Back in the day all these projects created and strengthened the cultural image of Azerbaijan in the eyes of artistic people abroad. It is safe to say that over the years from the mid-90s to the mid-2000s the contribution of SoNoR ICCM to the creation of Azerbaijan's image abroad was greater than that of many government art institutions put together. The Group and its management were building cultural connections between many countries that have participated in joint projects. The German Embassy and the GermanAzerbaijan Culture Society "Kapellhaus" often partnered with SoNoR; and the German Kirche (Church of the Saviour, Baku) was a favorite concert hall. Three German-speaking conductors directed the ensemble at different times. The composers from Austria, Holland and Sweden specifically wrote music for the ensemble. It is not a surprise that the ensemble gave the largest number of concerts in German-speaking countries. They also gave a lot of performances and workshops and established multiple creative contacts in Georgia and Ukraine; the band, in fact, fulfilled several projects (conferences, concerts and workshops) in these post-Soviet countries. Unlike his German-speaking colleagues, the Ukrainian conductor V. Runchak remained a frequent and welcomed guest on the Baku stage even after the collaboration with SoNoR had finished. In 2007-08 and 2010-11 he became the chief conductor of the concert series "Zamanla üz-üze" with the State Chamber Orchestra that was organized by the Azerbaijan Ministry of Culture and featured contemporary compositions by composers from different countries. Thus, the work started by SoNoR ensemble continued under a government leadership. 
The history of the ensemble was inspiring: there were several attempts to create different lineups of musicians and perform different types of music in Baku that were quite successful and resulted in creation of quartets and even a privately-funded string orchestra. All these groups, however, did not last long. Based on the past experience (including that of organizing the "Modern Sound Ensemble" (Turkey), the piano unit at the Antalya Conservatory (Turkey), the international pianist competition "Edelweiss" (Austria)) and knowing the situation in most post-Soviet countries "from the inside" the author will try to analyze the reasons for such outcome by the example of Azerbaijan. Countries with similar political, economic and cultural environment are likely to have similar results. There are several reasons for this:

1. the inability to confront governmental musical institutions that have a hierarchy and a budget;

2. the insufficient sponsorship and management;

3. the lack of a clear artistic direction and a plan for further action (ideology);

4. the lack of international relations;

5. and finally - friendly team spirit.

Let us start from the end. SoNoR, especially during the period of its formation (1995-1998), was a circle of close friends who, despite some temporary internal disagreements, disputes and discomfort, made concessions to each other for the sake of friendship. And the performance of modern music, despite the lack of fees and often public encouragement, was a way of self-expression, an ideology even. Friendship of the founders was one of the most important factors as practice had shown.

The international relationships in the early years went through the maestro F. Karaev and his Yeni Musiqi Society. The development of the ensemble and its projects went along with a gradual accumulation of their own connections which played an important role in further plans. Fragments of these connections helped the ensemble's successor - the Con Tempo ensemble - to form and develop.

Only very experienced musicians who know what they want can become ideological leaders of ensembles. If young groups, however, have no such leaders, their position is usually taken by either teachers or composers/theorists of the same generation. If there is an ideological enthusiast in the band, the band is very lucky. SoNoR was lucky to have such ideologist in the artistic director E. Mirzoev who was a three dimen- sional musician: a composer, an originator of programs and a drummer - all in one. Finding such a leader is a great success.

Sponsorship is one of the critical points in the development of any privately run band as experience shows. It usually depends on band's success, leader/ manager's charisma or partners' mutual benefit.

At first SoNoR did not have sponsors, they appeared only after several years of successful work. Many groups usually break up during this period. Sponsors' motifs are understandable, they want to see themselves on "successful" posters; this is the law of nature, so the hard work and manager's charisma are of crucial significance.

Confrontation with the government institutions is one of the most "invisible" currents. Musical state institutions in the post-Soviet countries include, among others, the Composers Unions with the chairmen and secretaries; State Chamber and Symphony Orchestras with the conductors; State Philharmonics, Concert Halls and Opera Theaters with the directors; Music academies and music schools with the senior management. In theory, they should not interfere with the young team, but practice and life show something completely different:

- The Composers Union chairmen often "disapprove" of the work of one or another young composer if they are not a member of the Union; they even often do everything possible to obstruct their performance (place pressure upon concert halls managers, "exclude" from the Plenum concerts, etc.). As a result, musician's rehearsals time and hopes - everything goes down the drain.

- The orchestras and conductors do not let orchestra musicians participate in other bands' concerts, even if there is no work in the orchestra at the time; they "advise" not to get involved, so to speak, for this musician's own "good".

- If musicians need instruments that they do not have and which are available only in the Philharmonic, the Opera or in some Concert Hall (usually it is large or rare instruments), this is most likely to become a problem as it is almost impossible to get the instruments from a director even if it is for one concert. You need an official paper from another music institution (for example, from the Composers Union, but they "do not approve", as we know), and even if you have this paper, it is still hardly possible to get the instrument; what is really needed is personal connections. 
- The concert hall rent is fantastically expensive; and it is not advised to even try without an official paper from an official organization.

- Rooms for rehearsals. Classes or small halls are needed for rehearsals, and they are located either in the Academy or in the musical schools.

All more or less decent musical bands come across these "underwater rocks" and quite often "crash" against them, especially if there is no strong sponsorship or government support.

The time when SoNoR was founded was referred to as "the wild nineties"; and all these government institutions were in confusion: no budget but plenty of fear of being shut down; the demise of the USSR and lawlessness in all spheres of life left them in a state of turmoil. There was almost no concert life in the country, musicians worked almost out of sheer enthusiasm.

SoNoR appeared out of nowhere and filled that niche. Musicians whom nobody needed began to play the music of composers whom nobody needed and give concerts which nobody needed on some godforsaken stages almost out of sheer enthusiasm. The ensemble solved its problems with youthful eagerness and a little bit of adventurism: they rehearsed in the guitarist's empty apartment where they were visited by bohemian friends and acquaintances some of which would later help the group in every possible way throughout their musical "adventures." The festivals and concerts organized by SoNoR and its successor in Baku hopefully contributed to the broadening of musical horizons of Azerbaijani students and the musical public of that time.

In conclusion we could state that SoNoR ensemble was lucky as by a happy coincidence they did not have to face the many factors that young bands lament about. It all worked well:

- their artistic director was a complete erudite;
- the ideological partner was Yeni Musiqi Society;

- the manager was a business lady with professional musical education;

- they had a rehearsal "base" in the city center;

- their "support group" consisted of sympathetic bohemia and was represented by artists, actors, composers;

- they had little money and they got more accessible concert halls;

- they were a group of gifted young musicians ready to work almost for free (who were not burdened with family concerns, which is important);

- and finally, the timing was perfect.

All these factors could come together only in the reckless criminal nineties. Neither in the 80s, nor in 2000s, young performers would not want to work for free, no one would create a private musical society to become an alternative to the Composers Union, and probably no one would be altruistic enough to turn their apartment in the city center into a rehearsal hall... The 80 s were not the right time yet; the 2000s were already not the right time. To agree to a semi-criminal adventure to organize a free concert of modern music? In the 90s it was absolutely acceptable. To go to a famous director at his theater and suggest doing collaborative performances together? Possible. To invite various musicians from Europe who would come to Azerbaijan having no visa ordeals without anyone knowing who and why invited them? Also possible. These days it is almost impossible to do privately all of the above mentioned and send invitations to foreign musicians to obtain visas without involvement from the government agencies. The time of total control over everything was substituted by the period that was called "the nineties" — the grotesque time that made such phenomenon as SoNoR possible; the time that can be compared to a coal bed which, if sufficiently compressed, produces a diamond to the world.

Bibliography:

Dadashzade, Z. (2000). SoNoR'un musiqisi. Şerqi, N 4, Baku, s.22-23.

Karaev, Faradj. (1976). Sonata per duo esecutori. Russia-Azerbaijan.

Klänge aus dem musikalischen Chemiebuch. (14.08.2001). Die Welt, Germany.

Von Mattias, R. Entress. (13.08.2001). Spur zur alten Kultur, Berliner Morgenpost, Germany. 
Von Peter, Uemling. (14.08.2001). Viel Bedeutung und nur venig Balsam, Berliner Zeitung, Germany.

Дадашзаде, 3. А. (2002). Мы - это ведь тоже часть мира... . Музыкальная Академия, №1, Москва.

Макушкин, В. (2010). Современные тенденции в камерно-ансамблевой музыке. Вестник Челябинского государственного университета, № 11. С. 161-165.

Орлова, Л. (2008). Камерно-инструментальные ансамбли Г. Гореловой: черты стиля и особенности интерпретации. Научные труды Белорусской государственной академии музыки. Выпуск 17.

Переверзева, М. В., Сигида, С. Ю., \& Сапонов, М. А. (Eds.). (2019). История современной музыки: Музыкальная культура США ХХ века: учебник для бакалавриата и специалитета. Москва: Юрайт. С. 383

Фархадов, Р. (05/07/2020). Вся правда о джаз-мугаме? Retrieved from https://azlogos.ru/jazz-mugam/

\section{References:}

Dadashzade, Z. (2000). SoNoR'un musiqisi. Şerqi, N 4, Baku, s. 22-23.

Dadashzade, Z.A. (2002). We are also part of the world ... Musical Academy, №1, Moscow (in Russian).

Farhadov, Rauf. (2020, July 05). The whole truth about jazz mugam? Retrieved from https://azlogos.ru/jazz-mugam/ (in Russian).

Karaev, Faradj. (1976). Sonata per duo esecutori. Russia-Azerbaijan.

Klänge aus dem musikalischen Chemiebuch. (14.08.2001). Die Welt, Germany.

Makushkin, V. (2010). Modern trends in chamber ensemble music. Bulletin of the Chelyabinsk State University, N 11. P. 161165 (in Russian).

Orlova, L. (2008). Chamber-instrumental ensembles of G. Gorelova: features of style and peculiarities of interpretation. Academic works of the Belarusian State Academy of Music. Issue 17 (in Russian).

Pereverzeva, M.V., Sigida, S. Yu., \& Saponov, M.A. (Eds.). (2019). History of Contemporary Music: Musical Culture of the United States of the Twentieth Century: A Textbook for Undergraduate and Specialist Degrees. Moscow: Yurayt. P. 383 (in Russian).

Von Mattias, R. Entress. (13.08.2001). Spur zur alten Kultur, Berliner Morgenpost, Germany.

Von Peter, Uemling. (14.08.2001). Viel Bedeutung und nur venig Balsam, Berliner Zeitung, Germany.

\section{Manuscripts:}

Alizadeh, Ali. (2000). "Cantabile... Dialoque in Raum", Azerbaijan.

Clarke, James. (2001). "Concetto speziale", United Kingdom.

Freisitzer, Roland. (2000). "Music for my daugther", Austria.

Karaev, Faradj. (2001). "Cancion di cuna", Russia-Azerbaijan.

Mammadova, Aliye. (2001). "Travel of sounds", Azerbaijan.

Mirzoev, Elmir. (1995). "Symbolic triangular silence", Azerbaijan.

Mirzoev, Elmir. (2000). "Visions and Echo", Azerbaijan.

Mirzoev, Elmir. (2005). "Fayyum portretlari II", Azerbaijan.

Österlink, Fredrik. (2000). "Love: Formal aspects", Sweden.

Runchak, Volodimir. (2000). "Homo Ludens I", Ukraine.

Sarhan, Françoix. (2000). "CRWTH", France. 


\section{Самір Мірзоєе}

Феномен ансамблю «SoNoR» $\mathbf{y}$ контексті зміни культурних парадигм на перетині тисячоліть

Анотація. Наприкінці тисячоліття з великими потрясіннями розвалилася колись велика імперія. Імперія, яка виграла Другу світову війну та стала однією з супердержав у світі на багато десятиліть. Імперія, яка створила абсолютно нову ідеологію і культуру, якої дотримувалися багато народів всередині неї і багато країн-супутників поза iii межами. Музика також була важливою складовою цієї культури. Під час розвалу величезної імперії багато країни, що були до неї приналежними, здобули свободу, але в той самий час - проблеми економічного, юридичного, військового та іншого плану. У числі цих проблем потрібно вирізнити також культурну та ідеологічну порожнечу. Азербайджан наприкінці минулого століття, як і інші пострадянські країни, переживав культурний шок і кризу. Усі державні культурні програми були зупинені. Ансамбль сучасної музики «SoNoR» як альтернатива цим програмам з’явився в найтемніші роки хаосу. Будучи створеним групою ентузіастів, він собою заповнив цю культурну прогалину та став на багато років іміджем країни у сфері сучасної музики. «SoNoR» організовував концерти, фестивалі, майстер-класи, прем’ери в країні та за кордоном, будував міжкультурні зв'язки з багатьма країнами. У статті розглядається феномен цього колективу в контексті того часу, на перетині тисячоліть, робиться спроба аналізувати причини його зльоту й розпаду.

Ключові слова: ансамбль «SoNoR», сучасна музика, академічна музика, міжкультурні зв’язки, азербайджанська музика, альтернативна програма, концерти, фестиваль, діалог культур.

\section{Самир Мирзоев}

Феномен ансамбля «SoNoR» в контексте смены культурных парадигм на стыке тысячелетий

Аннотащия. В конце тысячелетия с большими сотрясениями развалилась некогда большая империя. Империя, которая выиграла Вторую мировую войну и стала одной из супердержав в мире на многие десятилетия. Империя, создавшая абсолютно новую идеологию и культуру, которой придерживались многие народы внутри нее и многие страны-спутники вне ее границ. Музыка также была важной составляющей этой культуры. При развале огромной империи многие входившие в нее страны обрели свободу, но и вместе с тем - проблемы экономического, юридического, военного и другого плана. В числе этих проблем нужно выделить также культурную и идеологическую пустоту. Азербайджан в конце прошлого столетия, как и другие постсоветские страны, переживал культурный шок и кризис. Все государственные культурные программы были остановлены. Ансамбль современной музыки «SoNoR» как альтернатива этим программам появился в самые темные годы хаоса. Будучи созданным группой энтузиастов, он собой заполнил эту культурную брешь и стал на многие годы имиджем страны в сфере современной музыки. «SoNoR» организовывал концерты, фестивали, мастер-классы, премьеры в стране и за рубежом, строил межкультурные связи со многими странами. В статье рассматривается феномен данного коллектива в контексте того времени, стыка тысячелетий, делается попытка анализировать причины его взлета и распада.

Ключевые слова: ансамбль «SoNoR», современная музыка, академическая музыка, межкультурные связи, азербайджанская музыка, альтернативная программа, концерты, фестиваль, диалог культур. 